\title{
Mortality of factory workers in east London 1933-80
}

\author{
MURIAL L NEWHOUSE, G BERRY, AND J C WAGNER \\ From TUC Centenary Institute of Occupational Health, London School of Hygiene and Tropical Medicine, \\ London, UK, Commonwealth Institute of Health, University of Sydney, Australia, and MRC \\ Pneumoconiosis Unit, Penarth, UK
}

\begin{abstract}
The mortality of 3000 male factory workers, 1400 laggers, and 700 women factory workers in east London has been studied. The men were first employed between 1933 and 1964, the women between 1936 and 1942 . Textiles were produced until the late 1950 s as well as other asbestos products. Laggers were employed on contract in increasing numbers in later years. Crocidolite asbestos was used until the late $1950 \mathrm{~s}$ as well as amosite and chrysotile. Exposure of workers was graded according to the job into two categories, low/moderate and severe, and subdivided by duration of employment up to two years or longer. Mesothelial tumours accounted for $7.5 \%$ of the total mortality in men, and $9 \%$ in women with their longer follow up period. Lung cancer accounted for $20 \%$ of deaths in men and $14 \%$ in women. Both mesothelial tumours and lung cancer showed a dose response relationship. Histopathological examination of a series of predominantly postmortem specimens showed $22 \%$ of adenocarcinomas of lung among men and $21 \%$ in women. There was an excess of gastrointestinal tumours but no dose response relationship could be shown. Among severely exposed male factory workers there was an excess of deaths from cancer of the larynx and among severely exposed women of carcinoma of the breast and ovary. Twenty four deaths $(2 \%)$ were due to asbestosis. There is an indication that the incidence of mesothelial tumours is declining but a further period of observation is required for confirmation.
\end{abstract}

This paper reviews the mortality of workers employed at an asbestos factory in the East End of London making asbestos textiles and other asbestos products such as prefabricated cement pipes and using crocidolite until the mid-1950s as well as amosite and chrysotile asbestos. The factory opened in 1913 and continued in production until its closure in 1967. In the original study all male workers employed for 30 days or longer by 1964 were studied but were divided into three groups, those wholly employed before the introduction of the first asbestos regulations in May 1933 (438), those who worked both before and after the regulations (140), and those who worked entirely after the implementation of the regulations (4695). ${ }^{1}$ In the earliest group it was only possible to trace $50 \%$. The second group is small and experienced a pronounced change in environment owing to the introduction of the regulations. Therefore, although the mortality of

Received 3 October 1983

Accepted 14 November 1983 these two groups has continued to be monitored, subsequent analyses have only been undertaken of the post regulation group where the vital status of $95 \%$ of the workers was established.

In the orginal tracing exercise, through the Central Record Office of the Ministry of Pensions and National Insurance, ${ }^{2}$ only $30 \%$ of the female subjects were traced. The difficulty was chiefly due to change of name on marriage. Therefore a group of women was selected who started work at the factory between 1936 and 1942, a period when wartime records facilitated identification. The vital status of $77 \%$ of 932 women was established. ${ }^{3}$

The most recent analysis dates to December 1980 for men and to June 1980 for women. The maximum follow up period for men is 47 years and the minimum 16 , and for women the maximum period is 44 years and the minimum 38 . Most $(83 \%)$ of the male factory workers have been followed up for at least 20 years and $41 \%$ for longer than 30 years. The laggers were recruited later and $64 \%$ have been 
followed up for 20 years but only $9 \%$ for over 30 years.

At the outset of the investigation while the factory was still in production, each job was evaluated in terms of degree of exposure to asbestos dust and graded from light (1) to severe (6), a subjective evaluation as systematic dust surveys were not available. Laggers were separately categorised. Preliminary analysis showed little difference in mortality among the first three groups and they have been grouped together as low to moderate $(\mathrm{L} / \mathrm{M})$ exposure; each group is also categorised by duration of exposure-that is, those with up to two years' employment at the factory and those with longer than two years, many of whom had had more than 10 years' service. The laggers were not divided by duration of employment as they were predominently men employed on contract and in contrast to the factory workers many have worked previously or subsequently with asbestos.

\section{Classification of cause of death}

Causes of death were coded according to the 7th revision of the International Classification of Diseases. ${ }^{4}$ The cause of death coded was that given on the death certificate except that where a confirmed mesothelioma was found the mesothelioma was taken as the cause of death irrespective of what was on the death certificate.

As previously reported every effort is made to follow up deaths notified to us by OPCS. ${ }^{5}$ Necropsy reports are obtained and histological specimens requested; if no necrospy has been performed requests are made for material from surgical or biopsy specimens. All pathological material has been reviewed by one of us (JCW), and no case of mesothelioma has been included in the series unless confirmed.

Causes of death considered in this paper are: all cancers (ICD $140-205$ ), cancer of the lung (ICD $162-3$ but excluding mesotheliomas), gastrointes- tinal cancers (ICD $150-158$ but excluding mesotheliomas), cancer of the larynx (ICD 161), cancer of the breast (ICD 170), cancer of the ovary and Fallopian tubes (ICD 175), and asbestosis (ICD $523 \cdot 2)$.

\section{Analysis of mortality}

The mortality was assessed by comparing the number of observed deaths with the number expected based on sex, age, and period specific death rates for England and Wales. The expected deaths were calculated using the subject-years method. ${ }^{6}$ Death rates for England and Wales were taken from the Institute of Cancer tables, ${ }^{7}$ supplemented for the more recent years by the annual publications of OPCS. ${ }^{8}$ The first 10 years after first employment in the factory were excluded because of the latent period before asbestos induced tumours occur.

The ratio of observed to expected deaths $(\mathrm{O} / \mathrm{E})$ was used as a measure of excess mortality, and statistical significance was established by taking the observed as a Poisson variable with expectation equal to the subject-years expected. The two sided significance levels for excess mortality were obtained by doubling the probability in the upper tail. Comparisons of excess mortality between groups were based on likelihood methods."

\section{Results}

Tables $1-3$ show the mortality from all causes and for cancers in the four exposure categories for male factory workers, laggers, and the women factory workers. The excess of deaths from cancers is most pronounced among the production workers with severe and long exposure, but for men there was also an excess of lung cancer in low/moderate exposure. Mesotheliomas also occurred with low/ moderate exposure.

Table 1 Observed and expected mortality: men factory workers. Duration of follow up (years) $>10$

\begin{tabular}{|c|c|c|c|c|c|c|c|c|c|c|c|c|}
\hline \multirow{2}{*}{$\begin{array}{l}\text { No/subject-years } \\
\text { Cause of death }\end{array}$} & \multicolumn{3}{|c|}{$L / M \leqslant 2884 / 15573$} & \multicolumn{3}{|c|}{$L / M>2554 / 9588$} & \multicolumn{3}{|c|}{ Severe $\leqslant 2936 / 18881$} & \multicolumn{3}{|c|}{ Severe $>2512 / 9287$} \\
\hline & Obs & $\operatorname{Exp}$ & $O / E$ & Obs & $\operatorname{Exp}$ & $O / E$ & Obs & $\operatorname{Exp}$ & $O / E$ & Obs & $\operatorname{Exp}$ & $O / E$ \\
\hline $\begin{array}{l}\text { All causes } \\
\text { Lung cancer } \\
\text { Pleural mesothelioma } \\
\text { Gastrointestinal cancer } \\
\text { Peritoneal mesothelioma } \\
\text { Other cancers } \\
\text { Other causes }\end{array}$ & $\begin{array}{r}175 \\
24 \\
4 \\
14 \\
1 \\
7 \\
725\end{array}$ & 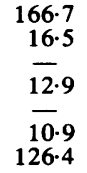 & $\begin{array}{l}1 \cdot 1 \\
\frac{1.5}{1 \cdot 1} \\
\frac{0.6}{1.0}\end{array}$ & $\begin{array}{r}144 \\
24 \\
6 \\
11 \\
4 \\
13 \\
86\end{array}$ & $\begin{array}{r}136 \cdot 0 \\
13 \cdot 2 \\
\overline{10 \cdot 4} \\
\frac{\overline{8}}{8 \cdot 6} \\
103 \cdot 8\end{array}$ & $\begin{array}{l}1 \cdot 1 \\
\frac{1 \cdot 8^{* *}}{1 \cdot 1} \\
\frac{1}{1 \cdot 5} \\
0.8\end{array}$ & $\begin{array}{r}252 \\
43 \\
9 \\
23 \\
11 \\
15 \\
151\end{array}$ & 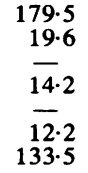 & $\begin{array}{l}1 \cdot 4^{* * *} \\
2 \cdot 2^{* * *} \\
\frac{1 \cdot 6^{*}}{1 \cdot 2} \\
1 \cdot 1\end{array}$ & $\begin{array}{r}247 \\
67 \\
12 \\
19 \\
13 \\
17 \\
119\end{array}$ & $\begin{array}{r}130 \cdot 5 \\
13 \cdot 9 \\
\overline{10 \cdot 5} \\
\frac{-}{8 \cdot 3} \\
97 \cdot 8\end{array}$ & $\begin{array}{l}1 \cdot 9^{* * *} \\
4 \cdot 8^{* * *} \\
-1 \cdot 8^{*} \\
\frac{-}{2 \cdot 0^{* *}} \\
1 \cdot 2^{*}\end{array}$ \\
\hline
\end{tabular}

* $\mathrm{p}<0.05 ;{ }^{* *} \mathrm{p}<0.01 ; * * * \mathrm{p}<0.001$.

Significance of excess mortality (two sided test).

$\mathrm{LM}=$ Low to moderate. 
Table 2 Observed and expected mortality: laggers. Duration of follow up (years) $>10$

\begin{tabular}{llll}
\hline No/subject-years & \multicolumn{3}{l}{$1369 / 16839$} \\
\cline { 2 - 4 } Cause of death & Obs & Exp & O/E \\
\hline All causes & 157 & 103.4 & $1 \cdot 5^{* * *}$ \\
Lung cancer & 38 & $10 \cdot 7$ & $3 \cdot 6^{* * *}$ \\
Pleural mesothelioma & 7 & - & - \\
Gastrointestinal cancer & 11 & $8 \cdot 1$ & $1 \cdot 4$ \\
Peritoneal mesothelioma & 6 & - & - \\
Other cancers & 10 & $7 \cdot 7$ & $1 \cdot 3$ \\
Other causes & 85 & 76.9 & $1 \cdot 1$ \\
\hline
\end{tabular}

${ }^{*} \mathrm{p}<0.05 ;{ }^{* *} \mathrm{p}<0.01 ;{ }^{* * *} \mathrm{p}<0.001$.

Significance of excess mortality (two sided test).

\section{LUNG CANCER}

Table 4 shows the deaths from lung cancer according to the duration of follow up. The excess of deaths from this cause tended to rise with increasing duration of follow up. Lung cancer mortality is significantly associated with both category and duration of exposure $(p<0.001)$ in men. The association is also found in women for duration of exposure $(\mathrm{p}<0.001)$, but there are too few women (only 99 in the L/M category) to give a sensitive comparison by exposure category.
PATHOLOGICAL MATERIAL

We analysed separately all cases of lung cancer where pathological material could be collected. This included the two earlier cohorts of men starting work before the implementation of the Asbestos Regulations in 1933 and all women employed between January 1936 and December 1942 and consisted of 234 men and 39 women certified as dying of lung cancer, excluding those subsequently identified as dying of mesothelial tumours. Lung and tumour tissues were obtained for review in 117 $(50 \%)$ of the male deaths from lung cancer and in $18(46 \%)$ of the 39 cases among women. Tumour tissue without lung tissue was obtained in a further 37 men and nine women, and in 10 the tumour type was determined by review of tissue from biopsy of glands or other organ. In all, $85 \%$ of the histological specimens examined were from necropsy material.

The cell type of tumour was designated according to the WHO classification of $1981^{10}$ (table 5). Among men squamous cell carcinoma was the most common (27\%) although oat cell, adenocarcinoma, and large celled tumours occurred with almost equal frequency. In the female series of 28 oat celled tumours were identified in 12 and adenocarcinoma

Table 3 Observed and expected mortality: women. Duration of follow up (years) >10

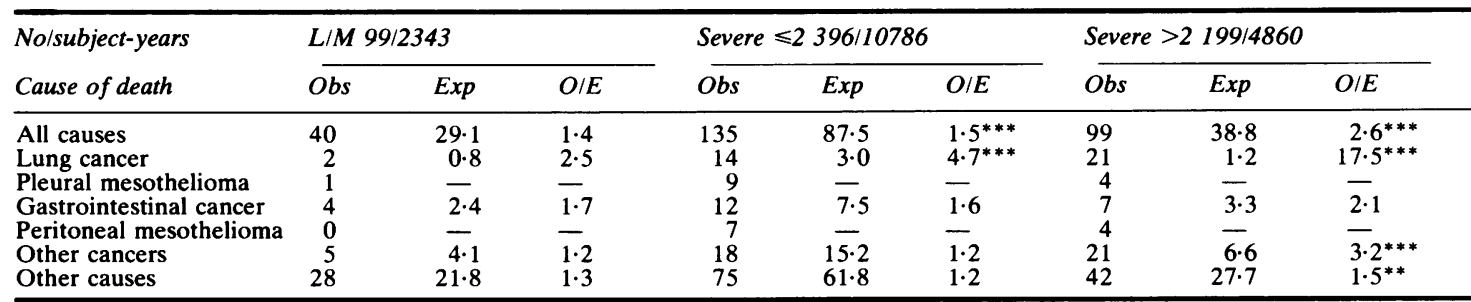

${ }^{*} \mathrm{p}<0.05 ;{ }^{* *} \mathrm{p}<0.01 ;{ }^{* * *} \mathrm{p}<0.001$.

Significance of excess mortality (two sided test).

$\mathrm{L} \mathbf{M}=$ Low to moderate .

Table 4 Deaths from lung cancer in male and female factory workers by duration of follow up and exposure category

\begin{tabular}{|c|c|c|c|c|c|c|c|c|c|}
\hline & \multicolumn{9}{|c|}{ Duration of follow up (years) } \\
\hline & \multicolumn{3}{|c|}{$10-19$} & \multicolumn{3}{|c|}{$20-29$} & \multicolumn{3}{|l|}{$\geqslant 30$} \\
\hline & Obs & $\operatorname{Exp}$ & $O / E$ & Obs & $\operatorname{Exp}$ & $O / E$ & Obs & $\operatorname{Exp}$ & $O / E$ \\
\hline $\begin{array}{l}\text { Men: } \\
\mathbf{U M} \leqslant 2 \text { years } \\
\mathbf{U M}>2 \text { years } \\
\text { Severe } \leqslant 2 \text { years } \\
\text { Severe }>2 \text { years }\end{array}$ & $\begin{array}{r}4 \\
7 \\
10 \\
22\end{array}$ & $\begin{array}{l}5 \cdot 4 \\
5 \cdot 0 \\
4 \cdot 7 \\
5 \cdot 2\end{array}$ & $\begin{array}{l}0 \cdot 7 \\
1 \cdot 4 \\
2 \cdot 1^{*} \\
4 \cdot 2^{* * *}\end{array}$ & $\begin{array}{l}10 \\
11 \\
16 \\
29\end{array}$ & $\begin{array}{l}6 \cdot 6 \\
5 \cdot 4 \\
7 \cdot 4 \\
5 \cdot 4\end{array}$ & $\begin{array}{l}1 \cdot 5 \\
2 \cdot 0^{*} \\
2 \cdot 2^{*} \\
5 \cdot 4^{* * *}\end{array}$ & $\begin{array}{r}10 \\
6 \\
17 \\
16\end{array}$ & $\begin{array}{l}4 \cdot 5 \\
2 \cdot 8 \\
7 \cdot 5 \\
3 \cdot 3\end{array}$ & $\begin{array}{l}2 \cdot 2^{*} \\
2 \cdot 1 \\
2 \cdot 3^{* *} \\
4 \cdot 8^{* * *}\end{array}$ \\
\hline $\begin{array}{l}\text { Women: } \\
\text { UMM } \\
\text { Severe } \leqslant 2 \text { years } \\
\text { Severe }>2 \text { years }\end{array}$ & $\begin{array}{l}1 \\
1 \\
0\end{array}$ & $\begin{array}{l}0 \cdot 1 \\
0 \cdot 3 \\
0 \cdot 2\end{array}$ & $\begin{array}{l}8 \cdot 3 \\
3 \cdot 5 \\
0 \cdot 0\end{array}$ & $\begin{array}{r}1 \\
3 \\
11\end{array}$ & $\begin{array}{l}0 \cdot 2 \\
0 \cdot 8 \\
0 \cdot 4\end{array}$ & $\begin{array}{l}4 \cdot 0 \\
3 \cdot 7 \\
29 \cdot 7^{* * *}\end{array}$ & $\begin{array}{r}0 \\
10 \\
10\end{array}$ & $\begin{array}{l}0 \cdot 4 \\
1 \cdot 9 \\
0 \cdot 7\end{array}$ & $\begin{array}{l}0 \cdot 0 \\
5 \cdot 4^{* * *} \\
14 \cdot 7^{* * *}\end{array}$ \\
\hline
\end{tabular}

${ }^{*} \mathrm{p}<0.05 ;{ }^{* *} \mathrm{p}<0.01 ;{ }^{* * *} \mathrm{p}<0.001$. Significance of excess mortality (two sided test).

$\mathrm{L} / \mathrm{M}=$ Low to moderate. 
Table 5 Histological type of tumour by sex in the 191 pathological specimens obtained

\begin{tabular}{|c|c|c|c|c|c|c|}
\hline \multirow[t]{2}{*}{ Histology } & \multicolumn{2}{|c|}{ Male } & \multicolumn{2}{|c|}{ Female } & \multicolumn{2}{|c|}{ Total } \\
\hline & No & (\%) & No & $(\%)$ & No & (\%) \\
\hline $\begin{array}{l}\text { Adenocarcinoma } \\
\text { Squamous } \\
\text { Oat cell } \\
\text { Mixed/anaplastic }\end{array}$ & $\begin{array}{r}36 \\
44 \\
39 \\
8\end{array}$ & $\begin{array}{r}(22) \\
(27) \\
(24) \\
(5)\end{array}$ & $\begin{array}{r}6 \\
6 \\
12 \\
0\end{array}$ & $\begin{array}{r}(21) \\
(21) \\
(43) \\
(0)\end{array}$ & $\begin{array}{r}42 \\
50 \\
51 \\
8\end{array}$ & $\begin{array}{r}(22) \\
(26) \\
(4)\end{array}$ \\
\hline $\begin{array}{l}\text { carcinoma } \\
\text { Total }\end{array}$ & $\begin{array}{r}36 \\
163\end{array}$ & $\begin{array}{l}(22) \\
(100)\end{array}$ & $\begin{array}{r}4 \\
28\end{array}$ & $\begin{array}{l}(14) \\
(100)\end{array}$ & $\begin{array}{r}40 \\
191\end{array}$ & $\begin{array}{l}(21) \\
(100)\end{array}$ \\
\hline
\end{tabular}

in six. In histological specimens where tumour tissue and lung tissue were available the degree of asbestosis was designated minimum, moderate, or severe, using a classificaton now generally adopted. " Table 6 shows the degree of asbestosis by tumour type in men. Only 12 were found with no histological evidence of asbestosis and a further 16 with a minimum degree of fibrosis.

Smoking histories were available for 104 subjects. There was one non-smoker, a man with adenocarcinoma, 14 male ex-smokers, and one woman. Among the 12 men who died of lung cancer without histological evidence of asbestosis five were current smokers, two ex-smokers, and in five the smoking history was not known. In seven of these 12 the duration of exposure was for less than one year, though in six of these the job they held entailed severe dust exposure.

\section{MESOTHELIOMAS}

At the time of analysis in 198060 male factory workers, 13 laggers, and 25 women factory workers had died of mesothelial tumours. The mesothelioma death rate, calculated as the number of tumours per 100000 years of exposure, showed a consistent rise with duration and severity of exposure (table 7). A higher proporion of the mesotheliomas were peritoneal in the severe groups $(35 / 69,51 \%)$ than in the low/moderate groups $(5 / 16,31 \%)$ but the difference was not significant. The laggers have a lower rate than severely exposed factory workers.

Since December 1970, 32 men and 13 women have died from mesothelioma. In $11(37 \%)$ men and six (46\%) women mesothelioma was not mentioned on the death entry (table 8). The causes of this high rate of confusion are various. Mesotheliomas are rare tumours with a diomorphic histology. A history of asbestos exposure many years before death may not have been disclosed to alert physicians and pathologists, and in some cases the death has been registered before histological examination of the tissues had taken place. Differentiating between adenocarcinoma of the lung and mesothelioma appears to give rise to particular difficulties; in three instances where death was certified as due to adenocarcinoma the tumour was reclassified as a mesothelioma, and in another three instances the diagnosis of mesothelioma was not accepted and the death was reclassified as due to adenocarcinoma of the lung. This confusion between mesotheliomas and adenocarcinomas has now been clarified by the use of specific tumour markers. Adenocarcinomas are positive to CEA staining using the peroxidase method. ${ }^{12}$

In the earlier paper ${ }^{13}$ predictions were given on the number of mesotheliomas to be expected after

Table 6 Degree of asbestosis by cell type of tumour in men

\begin{tabular}{|c|c|c|c|c|c|c|}
\hline \multirow[t]{2}{*}{ Tumour type } & \multicolumn{6}{|c|}{ Degree of asbestosis } \\
\hline & No & $\%$ & None & Min & Mod & Severe \\
\hline $\begin{array}{l}\text { Adenocarcinoma } \\
\text { Squamous cell } \\
\text { Oat cell } \\
\text { Mixed anaplastic } \\
\text { Large cell } \\
\text { Total }\end{array}$ & $\begin{array}{r}34 \\
31 \\
26 \\
5 \\
21 \\
117\end{array}$ & $\begin{array}{r}29 \cdot 0 \\
26 \cdot 5 \\
22 \cdot 0 \\
4 \cdot 2 \\
17 \cdot 9 \\
100\end{array}$ & $\begin{array}{r}1 \\
3 \\
3 \\
2 \\
3 \\
12(10 \%)\end{array}$ & $\begin{array}{l}5 \\
4 \\
1 \\
0 \\
6 \\
16(14 \%)\end{array}$ & $\begin{array}{l}15 \\
10 \\
10 \\
1 \\
7 \\
43(37 \%)\end{array}$ & $\begin{array}{r}13 \\
14 \\
12 \\
2 \\
5 \\
46(39 \%)\end{array}$ \\
\hline
\end{tabular}

Table 7 Mesothelioma rates per 100000 subject-years (sy) in men and women

\begin{tabular}{|c|c|c|c|c|c|c|c|c|c|c|c|}
\hline \multirow{2}{*}{$\begin{array}{l}\text { Category of } \\
\text { exposure }\end{array}$} & \multirow{2}{*}{$\begin{array}{l}\text { Exposure } \\
\text { (years) }\end{array}$} & \multicolumn{5}{|l|}{ Men } & \multicolumn{5}{|c|}{ Women } \\
\hline & & No & sy & $\begin{array}{l}\text { Mes } \\
P l\end{array}$ & $\begin{array}{c}\text { elioma } \\
\text { Per }\end{array}$ & $\begin{array}{l}\text { Meso ratel } \\
100000 \text { sy }\end{array}$ & No & sy & $\begin{array}{l}\mathrm{Me} \\
\mathrm{Pl}\end{array}$ & $\begin{array}{l}\text { lioma } \\
\text { Per }\end{array}$ & $\begin{array}{l}\text { Meso ratel } \\
100000 \text { sy }\end{array}$ \\
\hline $\begin{array}{l}\text { Low/moderate } \\
\text { Severe } \\
\text { Laggers }\end{array}$ & $\begin{array}{l}\leqslant 2 \\
>2 \\
\leqslant 2 \\
>2 \\
\text { All } \\
\text { durations } \\
\text { of service }\end{array}$ & $\begin{array}{r}884 \\
554 \\
936 \\
572 \\
1369\end{array}$ & $\begin{array}{r}15573 \\
9588 \\
18881 \\
9287 \\
16839\end{array}$ & $\begin{array}{r}4 \\
6 \\
9 \\
12 \\
7\end{array}$ & $\begin{array}{r}1 \\
4 \\
11 \\
13 \\
6\end{array}$ & $\begin{array}{r}32 \\
104 \\
106 \\
269 \\
77\end{array}$ & $\begin{array}{r}59 \\
40 \\
396 \\
199 \\
-\end{array}$ & $\begin{array}{r}1414 \\
929 \\
10786 \\
4860 \\
-\quad\end{array}$ & $\begin{array}{l}0 \\
1 \\
9 \\
4 \\
-\end{array}$ & $\begin{array}{l}0 \\
0 \\
7 \\
4 \\
-\end{array}$ & $\begin{array}{l}\overline{108} \\
139 \\
164 \\
-\end{array}$ \\
\hline
\end{tabular}


Table 8 Revision of underlying cause of death 1970-80

\begin{tabular}{lll}
$\begin{array}{l}\text { Underlying cause of death } \\
\text { on death entry }\end{array}$ & $\begin{array}{l}\text { Mesothelioma diagnosed on review } \\
\text { of histology }\end{array}$ \\
\hline Cancer of lung/bronchus & Male & Female \\
Carcinomatosis & 4 & 1 \\
Cancer of bowel & 3 & - \\
Other & 1 & - \\
Cancer of ovary & - & 1 \\
\hline
\end{tabular}

30 September 1972 in all women and in men excluding laggers. The above data now makes it possible to compare the observed number with those predicted at that time. Up to the end of 1975 another 23 deaths from mesothelial tumours had occurred compared with a range of predictions of between 17 and 22 . In the next five years (41/2 for women) 17 deaths from this cause occurred compared with a range of predictions of between 28 and 37 . The figure shows the cumulative number of mesothelioma plotted against calendar year. The reduced rate during $1976-80$ is encouraging but would need confirmation by several more years' data before we could be confident that it was a real effect. The reduction from 28 deaths from mesothelioma in the quinquenium $1971-5$ to 17 in $1976-80$ is not significant at the $5 \%$ level.

\section{AGE AT START OF EMPLOYMENT}

The mortality due to lung cancer and to mesothelioma separately have been examined in relation to the age at which a person started working in the factory, distinguishing between those who started before age 25 and those who were 25 or older. Table 9 shows the comparisons for men (excluding laggers) and women. The ratio of observed to expected lung cancers is similar in the two groups of men, but for women those who started young had a rate almost 12 times the expected figure compared with five times the expectation for those who had started when they were older. Mesothelioma rates were similar for the two age groups for both men and women. There was some imbalance between the two age groups for category and duration of exposure but, allowing for this, the differences in the excess lung cancer rates for women was significant $(p<0.05)$.

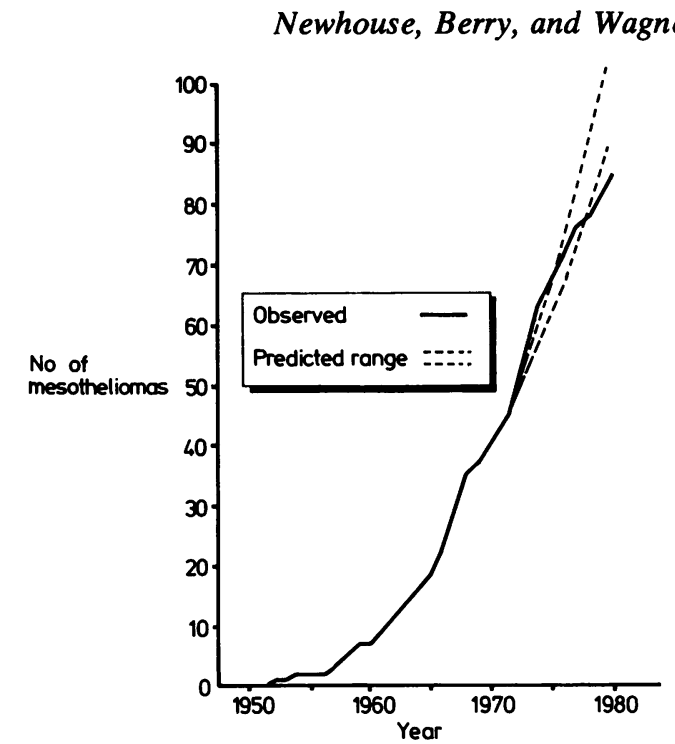

Cumulative number of mesotheliomas in factory workers (men and women); observed number compared with those predicted after 1972.

\section{GASTROINTESTINAL AND OTHER TUMOURS}

There is a statistically significant excess of deaths from gastrointestinal tumours among men (table 1). A similar excess was found in women, although it was not significant (table 2). Tests of significance of effect on duration and severity of exposure do not reach significant levels.

Nevertheless, as is seen in table 10 when the known mesothelial tumours are excluded from the calculation, the observed to the expected ratio of gastrointestinal tumours is higher in the severely exposed groups of men, though the trend is not obvious among women. Though here there is a twofold risk both among the women with low moderate exposure and with severe exposure for long periods.

Carcinoma of the larynx (table 11) is included in the "other" group. It is a rare cause of death and was not found among the laggers (expected 0.26 ) or women workers (expected 0.17). Three deaths in all were found among severely exposed factory workers with 0.81 expected $(p<0 \cdot 10)$.

Table 9 Age at first employment and mortality for lung cancer and mesothelioma

\begin{tabular}{|c|c|c|c|c|c|c|}
\hline & \multirow[b]{2}{*}{ Age started } & \multicolumn{3}{|c|}{ Lung cancer (excluding mesotheliomas) } & \multicolumn{2}{|c|}{ Mesotheliomas } \\
\hline & & Observed & Expected & Ratio & No & Rate $^{*}$ \\
\hline $\begin{array}{l}\text { Men } \\
\text { Women }\end{array}$ & $\begin{array}{l}\leqslant 24 \\
>25 \\
\leqslant 24 \\
>25\end{array}$ & $\begin{array}{r}38 \\
120 \\
22 \\
15\end{array}$ & $\begin{array}{r}13.5 \\
49.7 \\
1.9 \\
3.1\end{array}$ & $\begin{array}{r}2.8 \\
2.4 \\
11.6 \\
4.8\end{array}$ & $\begin{array}{l}34 \\
26 \\
15 \\
10\end{array}$ & $\begin{array}{l}119 \\
105 \\
145 \\
130\end{array}$ \\
\hline
\end{tabular}

${ }^{*}$ Per 100000 subject-years. 
Table 10 Observed to expected ratio of gastrointestinal cancers excluding peritoneal mesotheliomas

\begin{tabular}{lccc}
\hline Exposure (years) & Obs & Exp & OIE \\
\hline & Men & & \\
Low/mod $\leqslant 2$ & 14 & $12 \cdot 9$ & $1 \cdot 1$ \\
Low/mod $>2$ & 11 & $10 \cdot 4$ & $1 \cdot 1$ \\
Severe $\leqslant 2$ & 23 & $14 \cdot 2$ & $1 \cdot 6$ \\
Severe $>2$ & 19 & 10.5 & $1 \cdot 8$ \\
& Women & & \\
Low/mod $\leqslant 2$ & 2 & $1 \cdot 4$ & $1 \cdot 4$ \\
Low/mod $>2$ & 2 & $1 \cdot 0$ & $2 \cdot 0$ \\
Severe $\leqslant 2$ & 12 & $7 \cdot 5$ & $1 \cdot 6$ \\
Severe $>2$ & 7 & $3 \cdot 3$ & $2 \cdot 1$ \\
\hline
\end{tabular}

Table 11 Carcinoma of larynx among male factory workers

\begin{tabular}{lll}
\hline & Obs & Exp \\
\hline$L M \leqslant 2$ years & 0 & 0.4 \\
$\mathrm{LM}>2$ years & 0 & 0.3 \\
Severe $\leqslant 2$ years & 2 & 0.5 \\
Severe $>2$ years & 1 & 0.4 \\
All severely exposed & 3 & 0.8 \\
\hline
\end{tabular}

$\mathrm{L} / \mathrm{M}=$ Low to moderate.

Among the women workers mortality from carcinoma of the ovary and carcinoma of the breast have been followed up with care. One tumour certified as carcinoma of the ovary proved on histological examination to be a tubulopapillary mesothelioma. A further woman certified as dying of cancer of the lung proved to have secondary tumours from carcinoma of the ovary. Neither of these cases are included among the nine deaths shown in table 12. Among these, histological slides were available for four, in all of whom the diagnosis was confirmed. The total number of tumours remains low but the excess rates were higher in the severe and long exposure category, and this excess was statistically significant.

There were 12 deaths from cancer of the breast. Histology was reviewed and the diagnosis confirmed in four. In two lung tissue was available, in one there was severe asbestosis, and in the other minimal asbestosis. In another woman necrospy showed evidence of moderately severe asbestosis, but no slides were available to us. In a further woman who had a

Table 12 Carcinoma of breast and ovary among female factory workers

\begin{tabular}{llllll}
\hline Ex category & \multicolumn{2}{l}{ Ca of breast } & & \multicolumn{2}{l}{ Ca of ovary } \\
\cline { 2 - 3 } \cline { 6 - 6 } & Obs & Exp & & Obs & Exp \\
\hline UM all periods & 1 & 1.6 & & 2 & 0.6 \\
Severe $\leqslant 2$ years & 5 & 6.1 & & 2 & $2 \cdot 1$ \\
Severe $>2$ years & 6 & 2.6 & & 5 & $0.9^{* *}$ \\
\hline
\end{tabular}

$* * \mathrm{p}<0.01$

$\mathrm{LM}=$ Low to moderate. very long history of chest disease asbestosis appears to have been considered as her occupational history was known, but widespread secondaries from carcinoma of the breast caused her terminal illness, and no necropsy was performed. Evidence of concurrent asbestosis suggests severe exposure in a number of these women, but there was no significant evidence of dose response.

Among those with severe exposure there is an excess of deaths due to causes other than deaths from cancer. Chronic respiratory diseases including asbestosis are included in this disease group. Deaths due to asbestosis were most frequent among those with severe exposure for more than two years; nine among male factory workers, four among laggers, and five among women in this category. Another six deaths were due to this cause, all in men: two with severe but short exposure, two among laggers with short exposure, and two after low/moderate exposure of more than two years.

\section{Discussion}

This group of factory workers was exposed to both amphibole and chrysotile fibres. Exposure was admittedly heavy, and there was no recruitment to the cohort after 1964, well before the implementation of the Asbestos Regulations of 1969. Even in departments categorised as having "low to moderate exposure" fibre concentrations were higher than would be found under modern conditions. ${ }^{14}$ The severity of the asbestos effect on mortality may be gauged by the mortality from mesothelial tumours which accounted for almost $10 \%$ of the total mortality, and from lung cancer, where in groups followed up for more than 20 years there was a twofold excess mortality rising to fivefold in severely exposed men, and higher among women.

It has not been possible in this study to isolate groups of workers with exposure to a single fibre, but crocidolite was used in many departments, particularly in textiles, mattress making, and making of sectional asbestos pipes. The women in the cohort were all employed during the period when crocidolite was used. Some of the women worked in departments making filters for army gas masks from crocidolite asbestos from Australia, which was subsequently assembled in factories and has been studied by Wignall and Fox ${ }^{15}$ and Acheson et al. ${ }^{16}$

To improve the quality of the evidence efforts have been made to follow up deaths and obtain necropsy reports and histological material. As in the previous report ${ }^{5}$ further information was obtained in about half of the cases followed up. The pneumoconiosis panels contributed most of the material for the studies of carcinoma of lung and 
mesothelial tumours, but since the previous report of 1969 a further 17 mesothelial tumours have been identified by these methods and these have not been reviewed by the pneumoconiosis panels.

It has been a major interest to determine whether adenocarcinoma was the predominant type of lung cancer among this group of asbestos workers. A previous study of 86 workers with certified asbestosis who died of lung cancer found that among the 28 judged to have normal lung tissue or mild asbestosis, adenocarcinoma accounted for $25 \%$ of the cases; among the remaining 58 with moderate or severe asbestosis the proportion with adenocarcinoma rose to $38 \% .{ }^{17}$ The overall proportion was $34 \%$. In Whitwell's series of non-occupationally exposed patients from Liverpool the proportion of adenocarcinomas was $2 \%$ in the bronchial biopsy series, $9.4 \%$ in the operation specimen series, and $27.2 \%$ in the necropsy series. ${ }^{18}$ Whitwell pointed out that squamous and oat celled tumours are widely held to be the type of tumour caused by cigarette smoking, but it is suggested that cigarette smoking can exert a carcinogenic effect on different parts of the bronchial tree, usually producing squamous or oat cell tumours when proximal parts are affected and adenocarcinoma when distal parts are affected. From this study and the more complete study of $1972^{19}$ it is known that all but about $6 \%$ of the men in the cohort smoked, and that $60 \%$ of the women-a high figure at that period-also smoked. Asbestos fibre reaches the periphery of the lung and with the cocarcinogen of cigarette smoke produces the distal tumours: in this series, however, which is predominantly derived from necropsy specimens, the proportion of adenocarcinomas among men was $22 \%$, not suggesting a pronounced difference in cell type of lung cancer between this series and the Liverpool series. In Liverpool, however, the prevalence of pleural plaques in the general population is high and asbestos exposure may have been more common than in other parts of the country. Nevertheless, from the information available no particular cell type of lung cancer can be implicated.

An excess of risk of gastrointestinal cancer appears to be persistent in all groups among both men and women, but there is no clear evidence of dose response and the excess risk only reached a twofold level among women with long exposure (table 10). A similar magnitude of risk is found by Selikoff et al. . $^{20}$

Cancer of the larynx is an uncommon cause of death. In this study only three deaths were recorded, all among severely exposed workers; less than one was expected. Selikoff's study of insulators shows an excess of deaths from this cause, ${ }^{20}$ but the findings were negative among chrysotile miners and mil- lers. ${ }^{21}$ By contrast with the study of Stell and McGill of patients in Liverpool, ${ }^{22}$ a study of the occupational histories of patients in London with laryngeal diseases did not suggest that occupational exposure to asbestos was an important factor, ${ }^{23}$ but the number of patients included in the study was small. Cigarette smoking and alcohol consumption are important aetiological factors, and perhaps exposure to amphibole fibres combined with cigarette smoking exerts a multiplicative effect of the risk.

Among the severely exposed women there was an excess of deaths from carcinoma of the breast and carcinoma of the ovary, reaching statistical significance for carcinoma of the ovary. In the mortality studies of women assembling gas masks ${ }^{15} 16$ there was also a significant excess number of deaths from this cause. The evidence for excess number of deaths from carcinoma of the breast is less convincing, but Doniach showed that a high concentration of asbestos bodies occurred in the lungs of nonoccupationally exposed women dying from this cause. ${ }^{24}$ Among the four women in this study where further information is available evidence was found, suggesting exposure had been heavy.

In this study $39 \%$ of the female cohort factory workers, $28 \%$ of the male factory workers, and $11 \%$ of the laggers have died. All the women workers have been followed up for more than 30 years. Over $80 \%$ of the male factory workers and $64 \%$ of the laggers have had 20 years' or longer follow up. Although no dust measurements were available, there is evidence of dose response relationship for both mesothelial tumours and cancer of the lung. In total, 1249 of the 4949 workers have died compared with an expected number of deaths of 872 (tables $1-3)$. Thus there was an excess of $377(30 \%)$. Of the excess, 154 were due to lung cancer (233 observed, 79 expected), 98 to mesothelioma, and 24 to asbestosis. These three causes, which are all well established as being related to asbestos exposure, accounted for an excess of 276 deaths. There was an excess of 64 due to other cancers (207 observed, 143 expected), and it is less certain to what extent these could be attributed to asbestos exposure. The remaining causes accounted for an excess of only 37 deaths ( 687 observed, 650 expected), indicating that the causes of death selected for study included most, if not all, deaths associated with exposure. In summary, between $22 \%$ and $27 \%$ of all deaths were due to asbestos exposure.

A projection of mortality from mesothelial tumours made in $1976^{13}$ appears to date to have slightly overestimated the mortality from this cause, but in view of the interest, particularly in the United States, on the total toll of asbestos related cancers $^{25}{ }^{26}$ continued surveillance of this population, 
which experienced conditions fortunately not likely to recur, would appear to be desirable.

We thank Dr Olufunmike Obisesan for the analysis of the histological material which she undertook as part of her MSc project in 1982 and the OPCS and the DHSS records branch at Newcastle for their continued help. We also thank the numerous pathologists and coroners, too many to mention by name, who have provided us with reports and histological specimens, and we are grateful to Cape Industries Ltd, who at the outset of the study freely provided access to all their records. M L Newhouse was supported by a Medical Research Council grant.

\section{References}

' Newhouse ML. A study of the mortality of workers in an asbestos factory. Br J Ind Med 1969;26:294-301.

${ }^{2}$ Newhouse ML, Williams JM. Techniques for tracing past employees: an example from an asbestos factory. Br J Prev Soc Med 1967;21:35-9.

${ }^{3}$ Newhouse M, Berry G, Wagner JC, Turok M. A study of the mortality of female asbestos workers. $\mathrm{Br} J$ Ind Med 1972;29:134-41.

4 World Health Organisation. Manual of the international statistical classification of diseases, injuries and causes of death. 7th rev. Geneva: WHO, 1957.

${ }^{5}$ Newhouse ML, Wagner JC. Validation of death certificates in asbestos workers. Br J Ind Med 1969;26:302-7.

- Case RAM, Lea AJ. Mustard gas poisoning, chronic bronchitis, and lung cancer. Br J Prev Soc Med 1955;9:62-72.

7 Institute of Cancer Research. Serial mortality tables - neoplastic diseases. Vol 1. England and Wales 1911-70. London: Institute of Cancer Research, 1976.

${ }^{8}$ Office of Population Censuses and Surveys. Mortality statistics cause series DH2. London: HMSO, 1971-8.

' Berry G. The analysis of mortality by the subject-years method. Biometrics 1983;39: 173-84.

${ }^{10}$ World Health Organisation. International histological classification of tumours, No 1: histological typing of tumours. 2nd ed. Geneva: WHO, 1981.
"Pneumoconiosis Committee of the College of American Pathologists and the National Institute of Occupational Safety and Health. Report. Pathol Lab Med 1982; 106:543-96. (Special issue.)

12 Whittaker D, Sterrett GF, Shilkin KB. Detection of tissue CEAlike substance as an aid in the differential diagnosis of malignant mesothelioma. Pathology 1982;14:255-8.

${ }^{13}$ Newhouse ML, Berry G. Predictions of mortality from mesothelial tumours in asbestos factory workers. $\mathrm{Br} J$ Ind $\mathrm{Med}$ 1976;33: 147-55.

14 Newhouse ML, Berry G. Patterns of mortality in asbestos factory workers in London. Ann NY Acad Sci 1979;330:53-60.

is Wignall BK, Fox AJ. Mortality of female gas mask assemblers. Br J Ind Med 1982;39:34-8.

${ }^{16}$ Acheson ED, Gardner JM, Pippard EC, Grime LP. Mortality of two groups of women who manufactured gas masks from chrysotile and crocidolite asbestos: a 40 -year follow up. $\mathrm{Br} \mathrm{J}$ Ind Med 1982;39:344-8.

17 Whitwell F, Newhouse ML, Bennett DR. A study of the histological cell types of lung cancer in workers suffering from asbestosis in the United Kingdom. Br J Ind Med 1974;31:298303.

18 Whitwell F. The histopathology of lung cancer in Liverpool: a survey of bronchial biopsy histology. $\mathrm{Br} J$ Cancer 1961; 15:429-39.

${ }^{14}$ Berry G, Newhouse ML, Turok M. Combined effect of asbestos exposure and smoking on mortality from lung cancer. Lancet 1972;ii:476-9.

${ }^{20}$ Selikoff IJ, Hammond EC, Seidman H. Mortality experience of insulation workers in the United States and Canada 19431976. Ann NY Acad Sci 1979;330:91-117.

21 McDonald JC, Liddell FDK, Gibbs GW, Eyssen GF, McDonald AD. Dust exposure and mortality in chrysotile mining 1910 75. Br J Ind Med 1980;37:11-24.

22 Stell PM, McGill T. Asbestos and laryngeal carcinoma. Lancet 1973;ii:416-7.

${ }^{23}$ Newhouse ML, Gregory M, Shannon H. Etiology of cancer of the larynx. In: Wagner JC, ed. Biological effects of mineral fibres. Vol 2. Lyon: International Agency for Research on Cancer, 1980.

${ }^{24}$ Doniach I, Swettenham KV, Hathorn MKS. Prevalence of asbestos bodies on a necropsy series in East London. $\mathrm{Br} \mathrm{J}$ Ind Med 1975; 32: 16-34.

${ }^{25}$ Nicholson WJ, Perkel G, Selikoff IJ. Occupational exposure to asbestos: population at risk and projected mortality 19802030. Am J Ind Med 1982;3:259-311.

${ }^{26}$ Walker AM, Loughlin JE, Friedlander ER, Rothman KJ, Dreyer NA. Projections of asbestos related disease 1980-2009. JOM 1983;25:409-25. 